絵本レビューを情報源とする子どもの認知発達的反応
の収集・類型化とそれに基づく絵本の分類

笠松 美歩 $* 1 \cdot$ 上原 宏 $* 2 \cdot$ 宇津呂 武仁*3 ・齋藤 有 $* 4$

\begin{abstract}
本論文では，絵本に対する子どもの認知発達的反応が描写された絵本レビューに対してテキストマイニング技術を適用 し, 絵本に対する子どもの認知発達的反応事例を網羅的に収集した. 特に, 典型的な 5 種類の反応の事例に対して, 反応 の詳細および絵本の特徵に基づき, 合計 13 種類の下位分類を設定することができた. さらに, 以上の結果と, 既存の発 達心理学文献における知見との間の比較分析を行った結果, 発達心理学文献での報告事例の規模 ·種類とも上回る子ども の認知発達的事例を収集・類型化できることが分かった.
\end{abstract}

キーワード：絵本, レビュー分析, 認知発達的反応

\section{1. はじめに}

教育に関連する書籍は，特定の分野に関する知識を身につけ ることを目的としたものが多い，そうした中で絵本は，娛楽的 な表現形式をとりながらも，子どものさまざまな認知発達へ の効果が認められており $[1,25]$, その点で特定分野の知識習得 を目的とした一般の教育関連書籍にはない特徵を有する。ま た，絵本は活字を読むことができない幼児を主たる対象とする ため, 親や保育者の読み聞かせによる刺激と, 絵による視覚刺 激によって，子どもの理解が成立するという点も他の書籍には ない特徴である。これらの点をふまえて, 発達心理学において は, 絵本が子どもの認知発達に果たす役割について様々な角度 からの研究が行われてきた（例えば，[3-6] 等)，特に，発達心 理学においては, 養育者や保育者による子どもへの絵本の読み 聞かせ場面における主要な要因としては, 聴き手である子ども の特性に関するもの, 読み手である養育者・保育者の特性, 具 体的には, 絵本の読み聞かせ方の特性に関するもの, 読み聞か せに用いられる絵本の特徵に関するものが指摘されている [3]. これらの中で, 例えば, 発達心理学においてもその重要性が指 摘され多くの研究が行われているテーマの 1 つとして, 絵本を 媒介として養育者と子どもの間のコミュニケーションを確立す

\footnotetext{
$\dagger \quad$ Collecting and Categorizing Infants' Developmental Reactions in Reviews on Picture Books and Classifying Picture Books Miho KASAMATSU, Hiroshi UEHARA, Takehito UTSURO, and Yu SAITO

*1 筑波大学大学院システム情報工学研究科

Graduate School of Systems and Information Engineering, University of Tsukuba

*2 秋田県立大学システム科学技術学部

Faculty of Systems Science and Technology, Akita Prefectural University

*3 筑波大学システム情報系

Faculty of Engineering, Information and Systems, University of Tsukuba

*4 聖德大学児童学部

Faculty of Child Studies, Seitoku University
}

るプロセスに着目した研究が挙げられる。一例として, 養育者 と子どもの間の絵本共有時間の違いと養育者・子ども双方にお ける行動の違いに関する研究 [7], 読み聞かせにおける養育者 の養育態度の違いと絵本に対する子どもの関わり方の違いに関 する研究 $[8,9]$ 等が挙げられる.

これらの発達心理学分野の従来研究では, 仮説に基づいて, 母親が子どもに絵本を読み聞かせる際の条件を様々に変化さ せ，後の認知発達における差異を測定して仮説を検証するとい う地道な活動を, 各研究者が独自に続けている. そのため, 大 量の事例データを体系的に収集することが難しいのが現状であ る. 特に, 子どもによる認知発達的反応の種類, および, 子ど もの認知発達に対する効果の程度と個々の絵本の種類や特徵と の間の相関の有無等に関して網羅的事例デー夕収集およびその 分析を行なうといった方向への展開は, これからの課題であ る. このことは特に, 従来の発達心理学研究において, 絵本の 読み聞かせと子どもの認知発達との関わりに関して得られた知 見と, 絵本の種類との相関に関する研究成果の蓄積の欠如にお いて顕著である。例えば, 発達心理学分野の研究事例 $[8,9,11]$ においても, 得られた知見とその研究で使用した絵本との間の 因果関係が強く, 研究で使用された絵本の範囲を超えて研究成 果の知見が一般化できるか否かを示すためには, 別の角度から の新たな研究の取り組みが不可欠である。この例に見られるよ うに, 子どもの認知発達の様々な局面において効果があること が予測される多種類の絵本の事例を大規模に収集しそれらを類 型化すること, および, 各種類の絵本が, それぞれどのような 種類の認知発達を子どもにもたらすのかについての知見を体系 的に整理することは今後の発達心理学分野が取り組むべき大き な課題の一つである.

この現状をふまえ, 本論文では, 従来の発達心理学研究にお ける方式のように, 養育者や保育者が子どもに絵本の読み聞か せを行う様子を収録し, その内容を 1 つ 1 つ分析する方式と は異なり, 絵本のレビューが書き込まれるサイトを情報源とし て, 絵本に対する子どもの認知発達的反応が描写された絵本レ ビューを収集してこれを分析対象とする方式を提案する．本論 
文で情報源とする絵本レビューサイトにおいては，実際に絵本 の読み聞かせを行った養育者や保育者が，絵本の読み聞かせを 行なった際の様子や絵本への感想，絵本に対する子どもの反応 の有無やその反応の様子など，多岐多様な情報を記載してい る，本論文では，特に，それらの絵本レビューの中から，実際 に絵本に対する子どもの認知発達的反応の様子が大規模に収集 可能であることを示す，さらに，本論文では，0 6 歳の子ども が絵本に対して認知発達的反応をする場合の中心的な反応の事 例として，「じっと見る・じっと聞く」，「指さす」，「真似をす る」,「ごっこをする」，「物語に入り込む・感情移入する」の 5 種類の反応に着目し, 絵本レビューよりそれらの反応事例を網 羅的に収集する，また，それとともに，それらの子どもの反応 が特に多く観測される絵本タイトルもあわせて網羅的に収集す る。本論文に执いて以上を行なった結果，子どもの反応が特に 多く観測される絵本タイトルとして全 44 冊を選定することが できた，さらに，上述の 5 種類の反応別にこれらの全 44 冊の 絵本を特徴付けたところ, 絵本と反応の組み合わせにして合 計 64 組の組み合わせを認定することができた，また，これら の組み合わせ全体で観測された子どもの反応の推定総数は, 約 770 例となった，さらに，上述の 5 種類の子どもの反応に対し て, 子どもの反応の詳細拐よび絵本の特徴に基づく下位分類を 行うことによって, 子どもの反応および絵本の類型化を行なっ た。 その結果， 5 種類の反応全体に扔いて合計 13 種類の下位 分類を設定することができた

また，本論文では，既存の発達心理学文献を対象として絵本 に対する子どもの認知発達的事例を収集し，絵本レビューを情 報源とする絵本事例収集結果，および，子どもの認知発達的反 応の収集・類型化の結果と, 既存の発達心理学文献における知 見との間で比較分析を行った，その結果，本論文の提案方式に よって絵本レビューから収集した子どもの認知発達的反応事例 によって, 従来の発達心理学文献に抄ける知見を裏付けること ができた。ささらに，発達心理学文献での報告事例の規模・種類 とも上回る子どもの認知発達的事例を収集・類型化することが できた，以上の結果によって，本論文の提案方式が有効である ことを示すことができた

\section{2. 絵本レビューを対象とする子どもの認知発 達的反応の分析のための研究資源}

\section{1 絵本レビューサイト「絵本ナビ」}

本論文では，絵本情報サイト「絵本ナビ」 $\rfloor^{1}$ に読者が書き込ん だレビュー（以降，レビュー）を分析の対象とする，絵本ナビ は，絵本打よび児童書約 68,700 タイトルに関する出版社，著 者，あらすじなどの基本情報の他，大量のレビュー（2017 年 8 月現在で約 35 万 2 千レビュー）が書き込まれる国内最大級 の絵本㧍よび览童書に特化した情報サイト（表 1) である，絵 本ナビの基本統計情報抢よび 0 6 歳の各年齢を対象とするレ ビュー数を表 1 に示す（ただし，各年齢ごとのレビュー数は絵 本ナビの検索機能から得られる情報である)。また，絵本ナビ に書き込まれたレビューの例を図 1 に示す。この例のように，

http://www.ehonnavi.net
表 1 絵本情報サイト「絵本ナビ」 (a)「絵本ナビ」基本情報

\begin{tabular}{|c|c|c|c|c|}
\hline サービス開始 & 揭載タイトル数 & $\begin{array}{c}\text { 月間ユニーク } \\
\text { ユーザー数 }\end{array}$ & 登録会員数 & レビュー数 \\
\hline 2002 年 4 月 & 68,703 作品 & 110 万人 & 46 万人 & 352,601 件 \\
\hline
\end{tabular}

(b)「絵本ナビ」年齢別レビュー数 ( 0 ～6 歳)

\begin{tabular}{|l|l|l|l|l|l|l|}
\hline 歳代 & 1 歳代 & 2 歳代 & 3 歳代 & 4 歳代 & 5 歳代 & 6 歳代 \\
\hline
\end{tabular}

\begin{tabular}{|l|l|l|l|l|l|l|}
\hline 7,999 & 15,176 & 25,618 & 30,752 & 27,471 & 23,918 & 18,474 \\
\hline
\end{tabular}

うんとこしょどっこいしょ！

\section{口ロさん 30代·ママ·OO県 男の子2歳}

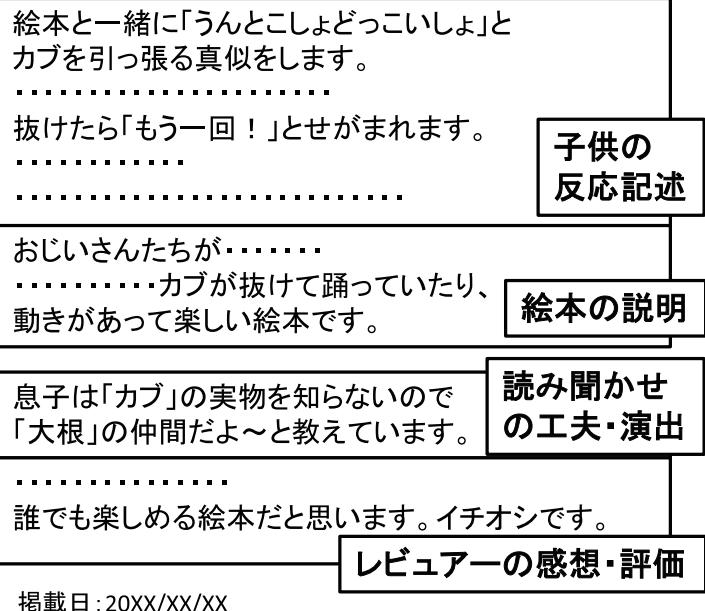

図 1 「絵本ナビ」のレビュー書き达み例

多くのレビューに扔いて, 絵本の読み手 (以降, レビュアー) の感想や行動を描写した記述と, 聞き手である子どもの反応を 描写した記述が混在している。文献 [10] では, 絵本ナビ中の レビューを人手分析し，絵本に対する子どもの反応の描写が含 まれる割合について報告している。

\section{2 発達心理学における子どもの反応特徵の類型}

発達心理学に打けるこれまでの研究においては，子どもには 年齢に応じた認知発達の段階があり, 各発達段階に打いて異な る反応特徴が現れるとされている，ここで，子どもの年齢別反 応特徴に関する発達心理学の文献 [12-19,25]（このうち, 文 献 $[16,18,19,25]$ は，絵本に対する子どもの反応特徴を記述し たもの）をもとに，1歳前後から 3 歳前後以上の各年齢におい て中心的に現れる反応特徴を年齢ごとにまとめた結果を表 2 に 示す，表 2 から分かるように，低年齢では「指差し」，「身振 り」などの断片的な身体表現による反応が現れ，年齢が高くな るにつれて「ごっこ遊び」，「感情移入」，「なぜ？」という質問 など，意味的なまとまりをもつ連続した反応を示すようになる 傾向がある，さらに，表 2 においては，レビュー中に出現する これらの反応を表す表現を収集した結果を「レビュー中の特徴 
表 2 発達心理学の知見に基づく子どもの年齢別反応特徵およびレビュー中の特徵的表現

\begin{tabular}{|c|c|c|c|}
\hline 年齢 & 発達上の反応特徵 & 説明, 事例 & レビュー中の特徴的表現 \\
\hline \multirow[t]{3}{*}{1 歳前後 } & 身体＋言葉で表現 & $\begin{array}{l}\text { 言葉で言い表せないことは, 指差し, 身振りなどで示そうとす } \\
\text { る. 絵本を見るとその記憶がよみがえり, 手を伸ばして体ごと } \\
\text { かかわる. }\end{array}$ & $\begin{array}{l}\text { 手を伸ばし/手をのばし, 指指 } \\
\text { し/指差し/指差す, つかんで/つ } \\
\text { かもうと/つかみます }\end{array}$ \\
\hline & 視覚刺激への反応 & $\begin{array}{l}\text { 絵に反応. 特に食べ物の絵は, 圧倒的に子どもの関心が高い. } \\
\text { 物の絵本 (乗り物, 動物など) を見ることによって, 自分の知っ } \\
\text { ていることを確かめて喜ぶ. }\end{array}$ & じーっと/゙っと \\
\hline & ふり・つもり行動 & $\begin{array}{l}\text { 例:「ちょうだい」というと, 実際に存在しない物を渡すまね } \\
\text { をする. }\end{array}$ & ふりする \\
\hline \multirow{4}{*}{2 歳前後 } & $\begin{array}{l}\text { 繰り返しリズムへ } \\
\text { の反応 }\end{array}$ & $\begin{array}{l}\text { 擬態語・擬声語に反応.「ころりん」,「すっとんとん」など, 意 } \\
\text { 味はわからないが，響きが好きで真似する． }\end{array}$ & オノマトペ \\
\hline & 真似 & $\begin{array}{l}\text { 周囲の人・物, 身の回りの出来事など, いろいろなものの真似 } \\
\text { をする. }\end{array}$ & 真似/まねつこ \\
\hline & $\begin{array}{l}\text { 見立て・ふり・つも } \\
\text { り行動 }\end{array}$ & $\begin{array}{l}\text { 見立てるもの（例えば積み木）と実物（例えば食べ物）との間 } \\
\text { に何らかの共通性を見出す. 積み木を自動車に「見立て」る. } \\
\text { ネコになった「つもり」で遊ぶ. }\end{array}$ & 見立て, ふり \\
\hline & 簡単なごっこ遊び & $\begin{array}{l}2 \text { 人でいすを並べて汽車ごっこするなど, } 3 \text { 歳以降の本格的 } \\
\text { ごっこ遊びの基盤が形成される. }\end{array}$ & ごっこ \\
\hline \multirow[t]{3}{*}{$\begin{array}{l}3 \text { 歳前後 } \\
\text { 以上 }\end{array}$} & ごっこ遊び & $\begin{array}{l}\text { 絵本のストーリーやその一部を遊びの中で再現するようにな } \\
\text { る. また, 生活の中でも自分を想像上の人物（動物）と見立て } \\
\text { て行動することがある. }\end{array}$ & ごっこ \\
\hline & $\begin{array}{l}\text { 関係性·因果性への } \\
\text { 関心 }\end{array}$ & $\begin{array}{l}\text { 「どうして?」,「なぜ？」という質問を通じて不思議に思うこ } \\
\text { とのイメージをふくらませる，知的好奇心が高まる. } \\
\text { 例: 「おとうさんは，おとこだから新聞をよんで，おかあさん } \\
\text { は，おんなだから, 朝ごはんつくるんだ。」 }\end{array}$ & ? 」 \\
\hline & 物語に感情移入 & $\begin{array}{l}\text { 絵本の世界に入り込む．例：「ホンにはいったらおばあちゃん } \\
\text { 助けられるの。」 }\end{array}$ & 感情移入, 入り込んで \\
\hline
\end{tabular}

的表現」欄に示す ${ }^{2}$.

\section{3 分析対象とする子どもの反応特徵およびレビュー 中の表現}

本論文では, 表 2 のレビュー中の特徵的表現」欄の表現の うち，特に出現頻度および子どもの認知発達的反応を表してい る割合の高い表現として, 以下の 5 種類の表現を分析対象と する.

(a)「じっと」(「じっと」または「じーっと」)

(b)「指さし」

(c) $\lceil$ 真似」

(d)「ごっこ」

(e)「入り込んで + 感情移入」（「入り込んで」または「感情 移入」)

このうち,「じっと」は,「じっと」および「じーっと」を $1 つ$ の表現としたものであり, 以降の分析において，「「じっと」の 頻度」は,「じっと」の頻度と「じーっと」の頻度の和を表す. また，同様に，「入り込んで+感情移入」は，「入り込んで」お よび「感情移入」を 1 つの表現としたものであり，「「入り込ん で＋感情移入」の頻度」は，「入り込んで」の頻度と「感情移 入」の頻度の和を表す。

2 「関係性・因果性への関心」を示す子どもの反応特徵は, レビュー中 では疑問文の発話として出現し，その終端には『? 」』が多く用いら れる。このことから，本論文では，『? 」』を，「関係性・因果性への 関心」に対応するレビュー中の特徴表現として用いる.

\section{4 分析対象とする子どもの年齢および絵本の選定}

本論文では，絵本レビューにおいて分析対象とする子どもの 年齢を $0 \sim 6$ 歳とする. また, 本論文で分析対象とする絵本を選 定する際には, 絵本ナビにおけるレビュー数ランキングの上位 100 作品を候補とする. そして, この 100 作品中の絵本の各々 を $b$, 前節で述べた 5 種類の反応表現の各々を $e, 0 \sim 6$ 歳の子ど もの年齢の整数值の各々を $a$ として, 年齢 $a$ の子どもを対象と した絵本 $b$ についての全レビューのうちで, 反応表現 $e$ が出現 したレビュー数を $f(b, a, e)$ で表す. 次に, それらの $f(b, a, e)$ 件のレビューに対して人手によって,「当該反応表現 $e$ の描写 対象が実際に子どもの反応か否か」の判定を行い, $f(b, a, e)$ 件 のうち実際に子どもの反応が描写されていたレビューの件数を $f_{c}(b, a, e)$ によって表す3 (ただし, $f(b, a, e)>10$ の場合には, 10 件を無作為抽出して子どもの反応の有無の人手判定を行う ことによって $f_{c}(b, a, e)$ の推定值を算出する $)$. そして, 全年 齢（0 6 歳）および全表現における子どもの反応の観測数の総 和が 8 以上（次式）

$$
\sum_{a, e} f_{c}(b, a, e) \geq 8
$$

となる絵本 44 冊を分析対象とする. ここで, 全 44 冊における 子どもの反応表現の観測総数 (推定值) は 1,389 , 観測総数 (推

3 本論文で分析対象とした全 5 種類の反応表現（2.3 節）の各々にお ける「当該反応表現 $e$ の描写対象が実際に子どもの反応である」割 合は,「じっと」が約 80\%,「指さし」が約 95\%, 「真似」が約 $75 \%$, 「ごっこ」が約 60\%,「入り込んで+感情移入」が約 50\% であった。 
定値）最大となる絵本は「きんぎょがにげた」(観測総数（推定 值）は163）, 最小となる絵本は「打しいれのぼうけん」(観測総 数は 8), 全 44 冊の平均観測総数（推定值）は 31.6 であった.

\section{3. 子どもの認知発達的反応を用いた絵本の分 類および発達心理学文献の調查}

\section{1 絵本の分類手順}

次に, 各絵本 $b$ に対して, その絵本の特徴を示す子どもの反 応表現ごとに絵本を分類し，これを絵本および子どもの反応の 大分類とする。 ここで, 全 5 種類の反応表現「じっと」,「指さ し」,「真似」,「ごっこ」,「入り达んで+感情移入」のうちの 「じっと」については, 反応の特徴を精査して,

・対象年齢が 0 1 歳が中心となり，「(意味は理解していない かもしれないが) 絵をじっと見る・音をじっと聞く」という 反応，打よび，

・2 歳以上が中心となり,「感情移入してお話をじっと聞く」と いう反応,

に二分する．特に後者については，「入り込んで+感情移入」と いう反応を伴う場合も多く，相互に重複する事例が多く観測さ れるため，両者を融合したものを 1 つの大分類とし，合計で以 下の 5 分類とする.

(a)「じっと」（0 1 歳中心）（（意味は理解していないかもし れないが）絵をじっと見る・音をじっと聞く）

(b)「指さし」

(c) 「真似」

(d) 「ごっこ」

(e)「じっと (2 歳以上中心)」+「入り込んで + 感情移入」(感 情移入して㧍話をじっと聞く)

次に, 以下に示す 3 段階を経て, 絵本の分類を行った.

段階 1 絵本に対する反応の 13 下位分類を作成し, 分析対象絵 本 44 冊に打ける 50 絵本・年齢・ 反応組を 13 下位分類に 分類.

段階 $2\lceil そ の$ 他」以外の 13 下位分類中の 50 絵本 · 年齢 - 反応 組の頻度条件を導出.

段階 3 分析対象絵本 44 冊に対し, 50 絵本 ·年齢・ 反応組が満 たす頻度条件を再適用し，14 絵本・年齢・ 反応組を選定. 以下の各節では, 段階 1 から段階 3 についての詳細を述べる.

\subsection{1 絵本に対する反応の 13 下位分類の作成および 50 絵本・年齢・反応組の分類}

各絵本 $b$ を, 上述の 5 大分類のうちの 1 つ以上に分類する ために, 絵本 $b$ を対象として, 年齢 $a$ の子どもが実際に反応 $e$ をする描写が含まれていたレビューの件数 $f_{c}(b, a, e)$ の值が十 分に大きくなる年齢 $a$ と反応 $e$ の組を列挙する，ただし，その 際には，各絵本の特徵，および，各絵本に対する子どもの反応 の詳細な特徵を分析し, 上述の 5 大分類の各々に扔いて, 表 3 扔よび表 4 に示す「反応の詳細扔よび絵本の特徴に基づく下位 分類」を設定する。この手順に执いては，本論文の著者 1 名揖 よび著者以外の 1 名の合計 2 名が合意の上で,「その他」以外 の計 13 下位分類㧍よび 5 大分類それぞれに扔ける「その他」
の下位分類の合計 18 下位分類を設定した．また，その際には， 上記 2 名が合意のうえで，「その他」以外の計 13 下位分類に 分類される 50 絵本・年齢・ 反応組（全 44 冊の絵本は, ここで の絵本延へ 50 冊に 1 回だけ含まれるもの, 複数回含まれるも の, 1 回も含まれないものに分けられる）の分類を行なった。 これらの 50 絵本・年齢・ 反応組は, 具体的には, 表 3 㧍よび 表 4 に扔いて, 「反応の詳細㧍よび絵本の特徵に基づく下位分 類」欄が「その他」以外となる下位分類中の絵本の延べ合計数 である。

\subsection{2「その他」以外の 13 下位分類中の 50 絵本・年 齢・反応組の頻度条件}

次に, これらの 50 絵本・年齢・反応組を客観的に選定するた めの定量的条件を規定するために, 絵本 $b$ を対象として, 年齢 $a$ の子どもが実際に反応 $e$ をする描写が含まれていたレビュー の件数 $f_{c}(b, a, e)$ を用いた条件を設定した。 この条件を設定す るにあたって，まず，各絵本 $b$ ごとの子どもの反応を含むレ ビュー件数の最大值 $\max _{a^{\prime}, e^{\prime}} f_{c}\left(b, a^{\prime}, e^{\prime}\right)$ と, 年齢 $a$ と反応 $e$ の組 における子どもの反応を含むレビュー件数 $f_{c}($ b.a.e $)$ の比を表 す次式

$$
r(b, a, e)=\frac{f_{c}(b, a, e)}{\max _{a^{\prime}, e^{\prime}} f_{c}\left(b, a^{\prime}, e^{\prime}\right)}
$$

を導入する。 そして, 上述の 50 絵本・年齢・ 反応組を漏れな く選定するために, $f_{c}(b, a, e), r(b, a, e)$ を用いた最も厳しい条 件の 1 つとして，次の頻度条件を用いる ${ }^{4}$.

$$
\begin{aligned}
& \left\{\left(f_{c}(b, a, e) \geq 2\right) \wedge(r(b, a, e)=1)\right\} \\
\vee & \left\{\left(f_{c}(b, a, e) \geq 3\right) \wedge(0.75 \leq r(b, a, e)<1)\right\} \\
\vee & \left\{\left(f_{c}(b, a, e) \geq 4\right) \wedge(0.55 \leq r(b, a, e)<1)\right\}
\end{aligned}
$$

(2) 式に打ける 3 項のうちの第 1 項 $\left(f_{c}(b, a, e) \geq 2\right) \wedge$ $(r(b, a, e)=1)$ は, $r=1$, すなわち, 絵本 $b$, 年齢 $a$, 反応 $e$ に扔けるレビュー件数が, 絵本 $b$ に扔ける最大のレビュー 件数である場合, その年齢 $a$. 反応 $e$ 組を無条件に絵本 $b$ の 特徴とみなすための条件である. 分析対象絵本 44 冊に扔け る $\max _{a^{\prime}, e^{\prime}} f_{c}\left(b, a^{\prime}, e^{\prime}\right)$ の最小值は 2 であったため, $r=1$ を满た す組を漏れなく選定する条件を規定するために, $r=1$ であ り, かつ $f_{c}(b, a, e) \geq 2$ であるという条件を設定した，分析 対象絵本 44 冊を選定する際には, $\sum_{a, e} f_{c}(b, a, e) \geq 8$ ((1) 式) のみを使用したが，この条件で選定された絵本 44 冊に扔ける $\max _{a^{\prime}, e^{\prime}} f_{c}\left(b, a^{\prime}, e^{\prime}\right)$ の最小值が 2 であったことから, 今後, 本論 文に扔ける手法を利用する際には, 分析対象絵本の選定に打い て, $\max _{a^{\prime}, e^{\prime}} f_{c}\left(b, a^{\prime}, e^{\prime}\right) \geq 2$ という条件を追加する必要があると解

4 頻度条件の導出においては, $r(b, a, e)=1$, すなわち, 各絵本 $b$ に おいて最大頻度を示す年齢 $a$. 反応 $e$ の組であるか否かによって場 合分けを行い, $r=1$ の場合には無条件に選出し, $0<r<1$ の場合 には，次式を用いた領域を設定し条件を導いた。

$$
\bigcup_{j=i}^{k}\left\{\left(f_{c} \geq f_{c}^{j}\right)\right\} \wedge\left\{\left(r^{j} \leq r<1\right)\right\}
$$

上式は, 50 絵本 ·年齢 - 反応組に扔いて, $\left(f_{c}, r\right)$ の $f_{c}$ 次元への下 限, 抄よび, $r$ 次元への下限の積集合を求め, その一個以上の和集合 をとった領域を表す。 
表 3 絵本レビュー中の子どもの認知発達的反応に基づく絵本の分類および発達心理学文献との比較 (1)

\begin{tabular}{|c|c|c|c|c|c|}
\hline $\begin{array}{l}\text { 絵本の特徵 } \\
\text { を示す子ど } \\
\text { も反応 }\end{array}$ & \multicolumn{2}{|c|}{$\begin{array}{l}\text { 反応の詳細および絵本の特徵に } \\
\text { 基づく下位分類 }\end{array}$} & $\begin{array}{l}\text { 子ども } \\
\text { の年齢 }\end{array}$ & $\begin{array}{l}\text { 提案手法によって分類 } \\
\text { された絵本冊数/絵本夕 } \\
\text { イトル }\end{array}$ & $\begin{array}{l}\text { 各反応の実例が報告された発達心理学論文・書 } \\
\text { 籍 / 絵本冊数 / 絵本タイトル /子どもの年齢 }\end{array}$ \\
\hline \multirow{4}{*}{$\begin{array}{l}\text { じっと }(0 \sim 1 \\
\text { 歳が中心 }) \\
\text { (意味は理 } \\
\text { 解していな } \\
\text { いかもしれ } \\
\text { ないが) 絵 } \\
\text { をじっと見 } \\
\text { る・音をじ } \\
\text { っと聞く }\end{array}$} & \multicolumn{2}{|c|}{$\begin{array}{l}\text { オノマトペとシンプルな絵が特 } \\
\text { 徵の絵本において, 特にその特 } \\
\text { 徵に対して反応する }\end{array}$} & $0 \sim 1$ 歳 & $\begin{array}{l}5 \text { 冊 / がたんごとんがた } \\
\text { んごとん/ごぶごぶご } \\
\text { ぼごぼ/じゃあじゃあび } \\
\text { りびり/ぴょーん/もこ } \\
\text { もここ }\end{array}$ & 佐々木 [20]/ 1 冊 / 桃太郎 / 0 歳 \\
\hline & \multicolumn{2}{|c|}{$\begin{array}{l}\text { 顔の描画が特徵的な絵本におい } \\
\text { て, 特にその特徵に対して反応 } \\
\text { する }\end{array}$} & $0 \sim 1$ 歳 & $\begin{array}{l}4 \text { 冊/いいおかお/いな } \\
\text { いいないばあ/おつきさ } \\
\text { まこんばんは/おひさま } \\
\text { あはは }\end{array}$ & 仲本 [21]/ 1 冊 / かお かお どんなかお / 年齢不詳 \\
\hline & \multicolumn{2}{|c|}{$\begin{array}{l}\text { カラフルな色彩など絵が特徵の } \\
\text { 絵本において, } \\
\text { の反応をする見るなど }\end{array}$} & $0 \sim 1$ 歳 & $\begin{array}{l}5 \text { 冊/きゅっきゅっきゅ } \\
\text { つ/はらぺこあおむし/ } \\
\text { わたしのワンピース/あ } \\
\text { おくんときいろちゃん / } \\
\text { おててがでたよ }\end{array}$ & 該当する論文, 書籍なし \\
\hline & \multicolumn{2}{|l|}{ その他 } & 1 歳 & $\begin{array}{l}1 \text { 冊/しょうぼうじどう } \\
\text { しゃじぷた }\end{array}$ & 該当する論文，書籍なし \\
\hline \multirow{8}{*}{ 指さし } & \multicolumn{2}{|c|}{$\begin{array}{l}\text { 紛らわしい絵柄の中に絵本の } \\
\text { 中の登場物を描いた絵本に拈い } \\
\text { て, 挿絵の中から目的の対象物 } \\
\text { を探す }\end{array}$} & $1 \sim 2$ 歳 & $\begin{array}{l}3 \text { 冊/うずらちゃんのか } \\
\text { くれんぼ/きんぎょがに } \\
\text { げた/たべたのだあれ }\end{array}$ & 関根 [22] / 1 冊 / きんぎょがにげた / 1 歳 \\
\hline & \multirow[t]{2}{*}{$\begin{array}{l}\text { 具体的な物 } \\
\text { 体が描かれ } \\
\text { た絵本が対 } \\
\text { 象 }\end{array}$} & $\begin{array}{l}\text { 具体物を描いた挿 } \\
\text { 絵を指さす }\end{array}$ & $1 \sim 2$ 歳 & $\begin{array}{l}6 \text { 冊/がたんごとんがた } \\
\text { んごとん/おやすみなさ } \\
\text { いおつきさま/しろく } \\
\text { まちゃんのほっとけー } \\
\text { きぞうくんのさんぽ/ } \\
\text { たまごのあかちゃん/は } \\
\text { らぺこあおむし }\end{array}$ & $\begin{array}{l}\text { 外山 [23] / } 1 \text { 冊 / 絵本不明 / } 1 \text { 歳から } 2 \text { 歳のいず } \\
\text { れかの年齢 }\end{array}$ \\
\hline & & $\begin{array}{l}\text { 絵本外の実世界に } \\
\text { おいて, 挿絵の中 } \\
\text { の具体物と対応す } \\
\text { る実物を指さす } \\
\end{array}$ & $1 \sim 2$ 歳 & 1 冊 / だるまさんの & $\begin{array}{l}\text { 菅井 [24] / } 4 \text { 冊 / あーんあん / ここです/きん } \\
\text { ぎょがにげた/ノンタンの絵本 / 1 2 歳 }\end{array}$ \\
\hline & \multicolumn{2}{|c|}{$\begin{array}{l}\text { 挿絵の中で多数の登場物が小 } \\
\text { さく細かく描かれた絵本におい } \\
\text { て, 関心のある部分を指さす }\end{array}$} & $2 \sim 3$ 歳 & $\begin{array}{l}2 \text { 冊/ } 14 \text { ひきのあさごは } \\
\text { ん/からすのパンやさん }\end{array}$ & 秋田 [2] / 1 冊 / からすのパンやさん/ 3 歳 \\
\hline & \multirow{4}{*}{\multicolumn{2}{|c|}{ その他 }} & \multirow{4}{*}{$1 \sim 3$ 歳 } & \multirow{4}{*}{$\begin{array}{l}3 \text { 冊/きゆっきゅっきゅ } \\
\text { っ/こんとあき/よるく } \\
\text { ま }\end{array}$} & $\begin{array}{l}\text { 齋藤・内田 [8] / } 3 \text { 冊 / おふろだおふろだ/こいぬ } \\
\text { がうまれるよ/はじめてのおつかい/ } 2 \text { 歳, } 5 \text { 歳 }\end{array}$ \\
\hline & & & & & $\begin{array}{l}\text { 齋藤・内田 }[9] / 1 \text { 冊/ きつねのおきゃくさま/ } \\
3 \text { 歳, } 5 \text { 歳 }\end{array}$ \\
\hline & & & & & $\begin{array}{l}\text { 佐々木 }[20] / 1 \text { 冊 / ちへいせんのみえるところ / } \\
1 \text { 歳 }\end{array}$ \\
\hline & & & & & $\begin{array}{l}\text { 関根 [26] / } 1 \text { 冊 / ノンタンスプーンたんたんたん } \\
\text { / } 1 \text { 歳 }\end{array}$ \\
\hline
\end{tabular}

釈できる. 次に, (2) 式の第 2 項, 第 3 項は, 絵本 $b$ において, 年齢 $a$ と反応 $e$ におけるレビュー件数が, 絵本 $b$ における 2 位 以下のレビュー件数であった場合の条件を表している。本論文 においては, 絵本 $b \cdot$ 年齢 $a$ ・反応 $e$ の組におけるレビュー数 が一定の条件を満たしていれば，そのレビュー数が絵本 $b$ にお ける最大のレビュー件数でなくとも, 年齢 $a$ ・ 反応 $e$ を, 絵本 $b$ の特徴として有効であると見なす。具体的には，レビュー件 数 3 以上かつ絵本 $b$ における最大のレビュー件数の 0.75 倍以 上，または，レビュー件数 4 以上かつ絵本 $b$ における最大のレ
ビュー件数の 0.55 倍以上のレビュー件数であれば特徵として 有効であると見なす。

\subsection{3 絵本 44 冊に対する頻度条件の再適用による 14 絵本・年齢・反応組の選定}

もともと，本節（3.1 節）の目的は, 絵本に対する子どもの反 応を含むレビューに対して, 前節で求めた頻度条件を適用する ことにより，絵本・年齢・反応組の自動選定を行うことであっ た。そこで, 次に, 分析対象絵本 44 冊に対し, 前節で求めた 
表 4 絵本レビュー中の子どもの認知発達的反応に基づく絵本の分類および発達心理学文献との比較 (2)

\begin{tabular}{|c|c|c|c|c|c|}
\hline $\begin{array}{l}\text { 絵本の特徵 } \\
\text { を示す子ど } \\
\text { も反応 }\end{array}$ & \multicolumn{2}{|c|}{$\begin{array}{l}\text { 反応の詳細および絵本の特徵に } \\
\text { 基づく下位分類 }\end{array}$} & $\begin{array}{l}\text { 子ども } \\
\text { の年齢 }\end{array}$ & $\begin{array}{l}\text { 提案手法によって分類 } \\
\text { された絵本冊数/絵本夕 } \\
\text { イトル }\end{array}$ & $\begin{array}{l}\text { 各反応の実例が報告された発達心理学論文・書 } \\
\text { 籍 / 絵本冊数 / 絵本タイトル /子どもの年齢 }\end{array}$ \\
\hline \multirow{9}{*}{ 真似 } & \multirow{4}{*}{$\begin{array}{l}\text { 特徵的な言 } \\
\text { 葉を用いた } \\
\text { 絵本におい } \\
\text { て, その中 } \\
\text { の言葉を真 } \\
\text { 似する }\end{array}$} & $\begin{array}{l}\text { 真似する対象の言 } \\
\text { 葉=オノマトペ }\end{array}$ & $1 \sim 2$ 歳 & $\begin{array}{l}2 \text { 冊/ じゃあじゃあびり } \\
\text { びり/もこもこもこ }\end{array}$ & $\begin{array}{l}\text { 古市 [27]/ } 1 \text { 冊/もこもこもこ/2歳 } \\
\text { 近藤・辻元 }[28] / 1 \text { 冊/きたきたうずまき/ } \\
5 \sim 6 \text { 歳 (注: ADHJ 児) }\end{array}$ \\
\hline & & \multirow{3}{*}{$\begin{array}{l}\text { 真似する対象の言 } \\
\text { 葉=絵本中のセリフ }\end{array}$} & \multirow{3}{*}{$1 \sim 4$ 歳 } & \multirow{3}{*}{$\begin{array}{l}1 \text { 冊/はじめてのおつか } \\
\text { い }\end{array}$} & 秋田 [2] / 1 冊 / ノンタンのたんじょうび / 2 歳 \\
\hline & & & & & 齋藤 [11] / 1 冊/きつねのおきゃくさま / 5 歳 \\
\hline & & & & & 佐藤・西山 [29] / 1 冊 / おおきなかぶ / 5 6 歳 \\
\hline & \multirow{2}{*}{\multicolumn{2}{|c|}{$\begin{array}{l}\text { 食べ物や, それを食べる場面が } \\
\text { 出現する絵本において，食べる } \\
\text { 真似をする }\end{array}$}} & \multirow[t]{2}{*}{ 1 3 歳 } & \multirow[t]{2}{*}{$\begin{array}{l}6 \text { 冊/いいおかお/はら } \\
\text { ペこあおむし/いちご/ } \\
\text { くだもの/ぐりとぐら/ } \\
\text { なにをたべてきたの? }\end{array}$} & $\begin{array}{l}\text { 関根 [26] / } 1 \text { 冊 / ノンタンスプーンたんたんたん } \\
\text { / } 1 \text { 歳 }\end{array}$ \\
\hline & & & & & 角田 [30] / 1 冊 /すいかのたね / 年齢不詳 \\
\hline & \multirow{2}{*}{\multicolumn{2}{|c|}{$\begin{array}{l}\text { 特徵的なキャラクターが登場す } \\
\text { る絵本において, キャラクター } \\
\text { の動作の真似をする }\end{array}$}} & \multirow{2}{*}{$1 \sim 4$ 歳 } & \multirow[b]{2}{*}{$\begin{array}{l}7 \text { 冊/おててがでたよ/ } \\
\text { だるまさんの/だるまさ } \\
\text { んが/だるまさんと/ど } \\
\text { んどこももんちゃん/ } \\
\text { ぴょーん/しろくまちゃ } \\
\text { んのほっとけーき }\end{array}$} & 佐々木 [20] / 1 冊 / でんぐりでんぐり / 年齢不詳 \\
\hline & & & & & 佐々木 [31] / 1 冊 / いただきまあす / 年齢不詳 \\
\hline & その他 & & $1 \sim 3$ 歳 & $\begin{array}{l}4 \text { 冊/おつきさまこんば } \\
\text { んは/たまごのあかちゃ } \\
\text { ん/てぶくろ/ねないこ } \\
\text { だれだ }\end{array}$ & 該当する論文，書籍なし \\
\hline \multirow[t]{2}{*}{ ごっこ } & \multicolumn{2}{|c|}{$\begin{array}{l}\text { 物語性の強い絵本において, 物 } \\
\text { 語の再現をする }\end{array}$} & $2 \sim 4$ 歳 & $\begin{array}{l}\text { 冊/おおきなかぶ/て } \\
\text { ぶくろ/三びきのやぎの } \\
\text { がらがらどん }\end{array}$ & $\begin{array}{l}\text { 佐々木 [20] / } 4 \text { 冊 / めっきらもっきらどおんどん } \\
\text { / はじめてのおつかい/おおきなかぶ/こすずめ } \\
\text { のほうけん / } 2 \text { 歳, } 4 \text { 歳, 年齢不詳 }\end{array}$ \\
\hline & \multicolumn{2}{|l|}{ その他 } & $2 \sim 4$ 歳 & $\begin{array}{l}4 \text { 冊/あさえとちいさい } \\
\text { いもうと/えんそくバス } \\
\text { /くれよんのくろくん / } \\
\text { がたんごとんがたんご } \\
\text { とん }\end{array}$ & 該当する論文，書籍なし \\
\hline \multirow{5}{*}{$\begin{array}{l}\text { 「じっと }(2 \\
\text { 歳以上が中 } \\
\text { 心)」+「入り } \\
\text { 込んで+ 感 } \\
\text { 情移入」(感 } \\
\text { 情移入して } \\
\text { 抢話をじっ } \\
\text { と聞く) }\end{array}$} & \multicolumn{2}{|c|}{$\begin{array}{l}\text { 主人公が不安な気持ちになる場 } \\
\text { 面がある絵本に拀いて, 主人公 } \\
\text { の不安な気持ちに反応する }\end{array}$} & $2 \sim 6$ 歳 & $\begin{array}{l}5 \text { 冊/よるくま/こんと } \\
\text { あき/はじめてのおつか } \\
\text { い/あさえとちいさいい } \\
\text { もうと/おしいれのぼう } \\
\text { けん }\end{array}$ & 該当する論文，書籍なし \\
\hline & \multirow{4}{*}{\multicolumn{2}{|c|}{ その他 }} & \multirow{4}{*}{$2 \sim 6$ 歳 } & \multirow{4}{*}{$\begin{array}{l}2 \text { 冊/くれよんのくろく } \\
\text { ん/おへそのあな }\end{array}$} & $\begin{array}{l}\text { 秋田 [2] / } 2 \text { 冊 / ひとりぼっちのライオン / はじ } \\
\text { めておつかい/2 4 歳 }\end{array}$ \\
\hline & & & & & $\begin{array}{l}\text { 齋藤・内田 [9] / } 1 \text { 冊 / きつねのおきゃくさま / } \\
3 \text { 歳 }\end{array}$ \\
\hline & & & & & $\begin{array}{l}\text { 佐々木 }[20] / 6 \text { 冊/ペんぎんたんけんたい/はじ } \\
\text { めておおつかい/こぐまちゃんいたいいたい/だ } \\
\text { るまちゃんとだいこくちゃん/とんことり/ふた } \\
\text { りはいつも/2 4 歳, 年齢不詳 } \\
\end{array}$ \\
\hline & & & & & 佐々木 [31] / 1 冊 / どろんこハリー / 3 歳 \\
\hline
\end{tabular}

頻度条件の適用を再度行った。その結果, 分析対象絵本 44 冊 からは，3.1.1 節の手順によって得られた 50 絵本・年齢・反応 組（表 3 および表 4 の「反応の詳細および絵本の特徵に基づく 下位分類」欄が「その他」以外となる絵本・年齢・反応組）以 外に，新たに 14 絵本・年齢・反応組が得られた。これらの 14 絵本・年齢・反応組に対して, 本論文の著者 1 名および著者以 外の 1 名の合計 2 名が合意の上で, 表 3 および表 4 に示す「反 応の詳細および絵本の特徵に基づく下位分類」において,「年
齢 $a$ において観測される子どもの反応 $e 」 に$ に該当する大分類へ の分類を行なった，さらに，各大分類における「反応の詳細お よび絵本の特徵に基づく下位分類」のうちの「その他」の下位 分類へ, これらの 14 絵本 · 年齢 · 反応組を分類した. 以上の 結果を表 3 および表 4 に示す。 なお, 3.1.1節の手順によって 得られた 50 絵本・年齢・ 反応組が, 表 3 および表 4 の「反応 の詳細および絵本の特徴に基づく下位分類」欄において「その 他」以外に分類され, 各絵本における重要な特徴付けとなるの 
に対して，本節で得られたこれらの 14 絵本・年齢・反応組は, 前節の頻度条件適用の過程でやむを得ず抽出されはするもの の, 各絵本の特徵として位置付けるまでには至らない絵本・年 齢・反応組である.

\section{2 「反応の詳細および絵本の特徵に基づく下位分類」 への分類結果および発達心理学文献の調查}

本節では，前節および表 $3 \cdot$ 表 4 で述べた (a) (e) の大分類 の各々について，「下位分類」の詳細，および，各「下位分類」 ごとに発達的心理学文献の調査を行なった結果について述べる とともに，その詳細な調査・比較結果を表 $3 \cdot$ 表 4 「各反応の 実例が出現する発達心理学論文，書籍」他の欄に示す．

\subsection{1「「゙っと」(0 1 歳中心)（(意味は理解していな いかもしれないが）絵 をじっと見る・音をじっ と聞く)}

この大分類における子どもの反応および絵本は以下に下位分 類される

・オノマトペとシンプルな絵が特徵の絵本において，特にその 特徵に対して反応する,

・顔の描画が特徴的な絵本において，特にその特徵に対して反 応する,

・カラフルな色彩など絵が特徴の絵本において，じっと見るな どの反応をする，

・その他

この大分類は，0 1 歳という最も低年齢の子どもによる「絵 をじっと見る，音をじっと聞く」という反応が対象であり，対象 となる絵本も最も低年齢向けの絵と文章から構成される。「そ の他」以外の 3 つの下位分類のうち 2 つについては, 発達心理 学文献においても，各 1 件ずつ，子どもの反応事例が報告され ている. 残る 1 つの下位分類「カラフルな色彩など絵が特徵の 絵本」についても，絵本の特徵を紹介する文献の事例は見られ たが，子どもの反応を具体的に記録した文献ではなかった。

\subsection{2「指さし」}

この大分類における子どもの反応および絵本は以下に下位分 類される。

・紛らわしい絵柄の中に絵本の中の登場物を描いた絵本におい て，挿絵の中から目的の対象物を探す，

・具体的な物体が描かれた絵本において,

・具体物を描いた挿絵を指さす,

絵本外の実世界において，挿絵の中の具体物と対応する実 物を指さす,

・挿絵の中で多数の登場物が小さく細かく描かれた絵本におい て，関心のある部分を指さす,

-その他

この大分類は，上述の「じっと」(0 1 歳中心) の次に低年齢 の子どもによる反応が対象であるが，子どもの反応が分かりや すいことが特徵である。下位分類「紛らわしい絵柄の中に絵本 の中の登場物を描いた絵本において，挿絵の中から目的の対象 物を探す」の絵本では，探すべき対象が挿絵のどこかに描かれ

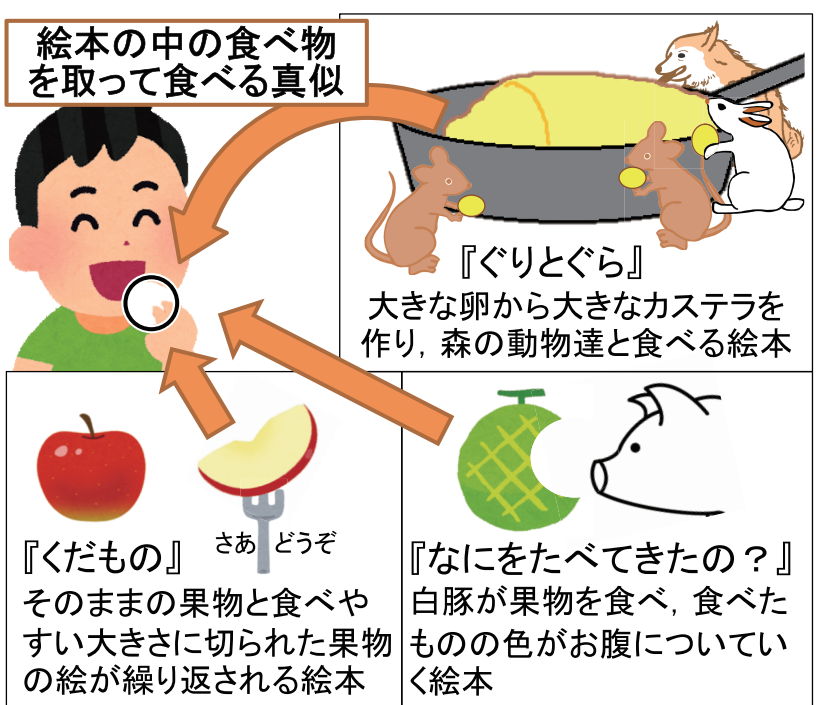

図２ 子どもの反応例：食べる真似

ており，挿絵の中を探して遊ぶ仕掛けが施されている。一方， 下位分類「挿絵の中で多数の登場物が小さく細かく描かれた絵 本において，関心のある部分を指さす」の絵本では，1 枚の挿 絵の中に多数の種類のキャラクターや物が描かれており，子ど もは自分の気に入った種類のキャラクターや物を選んで説明し たり，自分が好きであることの意思表明をしたりして遊ぶこと ができる。この大分類においては，いずれの下位分類において も, 発達心理学文献における子どもの反応の報告事例を見つけ ることができる

\subsection{3「真似」}

この大分類における子どもの反応および絵本は以下に下位分 類される.

・特徵的な言葉を用いた絵本において，その中の言葉を真似 する，

·真似する対象の言葉：オノマトペ

・真似する対象の言葉 : 絵本中のセリフ

・食べ物や，食べる場面が出現する絵本において，食べる真似 をする，

・特徵的なキャラクターが登場する絵本において, キャラク ターの動作の真似をする

•その他

この大分類はやや中高年齢の子どもによる反応が対象であ る。下位分類「特徵的な言葉を用いた絵本において，その中の 言葉を真似する」の絵本では，オノマトペや絵本中のセリフな どの簡単な言葉を真似するものが多い．図 2 に示す下位分類 「食べ物や，食べる場面が出現する絵本において，食べる真似 をする」の絵本では，「ぐりとぐら」のように，一連の料理の過 程が描かれる絵本において, 出来上がったものを食べる真似を するものや，「くだもの」や「なにをたべてきたの？」のよう に，目の前に現れた食べ物を食べる真似をするものがある。下 位分類「特徵的なキャラクターが登場する絵本において，キャ ラクターの動作の真似をする」の絵本では, 簡単な言葉によっ てキャラクターの動作を描写するものが多い。この大分類にお 
いては, いずれの下位分類においても, 発達心理学文献におけ る子どもの反応の報告事例を見つけることができる.

\section{2 .4 「ごっこ」}

この大分類における子どもの反応抄よび絵本は以下に下位分 類される.

・物語性の強い絵本において, 物語の再現をする,

•その他.

この大分類も，「真似」の大分類同様，やや中高年齢の子ども による反応が対象である，下位分類「物語性の強い絵本におい て, 物語の再現をする」の絵本では, 子どもが登場人物になり きり，絵本の物語を再現する，物語の構成としては，「おおき なかぶ」において, 無の収穫の際に, 無を引き抜く試みが失敗 すると協力者を一人増やして再度無を引き抜くことを試みる過 程を繰り返す（「おおきなかぶ」では，協力者が 5 人になって やっと成功する）例に挙げられるように, 類似するストーリー が繰り返される形式の絵本が多い.この下位分類においては, 発達心理学文献における子どもの反応の報告事例を見つけるこ とができる。

\subsection{5「じっと (2 歳以上中心)」+「入り込んで + 感 情移入」(感情移入してお話をじっと聞く)}

この大分類における子どもの反応および絵本は以下に下位分 類される.

・主人公が不安な気持ちになる場面がある絵本において, 主人 公の不安な気持ちに反応する，

・その他.

この大分類は, 相対的に高年齢の子どもによる反応が対象で ある。下位分類「主人公が不安な気持ちになる場面がある絵本 において，主人公の不安な気持ちに反応する」においては，登 場人物が不安な気持ちになる場面に㧧いてハラハラドキドキす るような物語の絵本が多い。この下位分類においては, 絵本の 特徵を紹介する文献の事例は見られたが, 子どもの反応を具体 的に記録した文献を見つけることはできなかった。

\section{3 考察}

以上の分類結果㧍よび発達心理学文献の調査結果から分かる ように，いくつかの下位分類を除いて，多くの下位分類におい て, 発達心理学文献において, それぞれの下位分類に該当する 子どもの反応事例が報告されている。 しかし, 各下位分類ごと に, 発達心理学文献全体での子どもの反応の報告事例数は約数 件から 1 件程度であり, 絵本の種類数も約数種類から 1 種類程 度である。一方, 本論文において, 絵本レビューから子どもの 反応が抽出された絵本の種類数は, 各下位分類ごとに絵本の種 類数が数種類程度あり, しかも, 子どもの反応が観測された絵 本レビュー数の総数は, 表 3 および表 4 で対象とした子どもの 反応全体で 770 例以上（この収集元は， 2.4 節で述べた，子ど もの反応表現の観測総数 (推定值) 1,389 例であり, このうち, 表 3 および表 4 の大分類に該当する事例数が 770 例以上であ る）である。また，下位分類「その他」を除くと，各下位分類 ごとに, 約 20 例程度から多いもので 100 例以上, 平均して 50
例以上である．また，子どもの反応の下位分類別に，子どもの 反応が収集できた絵本レビュー数は, 絵本間で平均して 12 例 以上であり, 以上の結果から, 発達心理学文献に打りる報告数 よりもはるかに多くの事例を観測できていることが分かる. 本 論文の方式によって, 絵本レビューから子どもの認知発達的反 応を収集することによって, 従来の発達心理学文献での知見を 裏付けるとともに, 発達心理学文献での報告事例の規模 · 種類 とも上回る事例を収集することができた，よって，本論文の提 案方式が有効であることを示すことができた.

また，発達心理学文献において報告された絵本全 30 冊のう ち, 本論文で分析対象として選定した 44 冊以外の絵本は計 24 冊 $(80 \%)$ であった。 つまり, 発達心理学文献において分析に 用いられた絵本の大半は, 絵本ナビにおいて, レビュー数が多 く子どもの反応の報告事例も多く収集される絵本とは別の絵本 であった.このことから, 本論文で得られる知見と, 発達心理 学におけるこれまでの成果拉よび子どもの認知発達的反応を記 録・分析するノウハウを相補的に利用することによって, これ までよりも効率よく, かつより多様な認知発達的現象を収集で きる可能性があると言える。

その他, 特に, 大分類 (b)「指さし」, および, (e)「じっと $(2$ 歳以上中心) $++\lceil 入 り$ 込んで+感情移入」において, 発達心 理学文献における絵本冊数が, 本論文で絵本レビューにおいて 子どもの反応が観測された絵本冊数よりも多くなっているが, これらの絵本が何らかの共通の特徵を持っており, 表 3 および 表 4 において「反応の詳細および絵本の特徵に基づく下位分 類」において設定した 13 種類の下位分類と同等の下位分類が 新たに設定可能か否かについての分析は, 今後の課題である.

\section{4. 関連研究}

本論文に関連して, 発達心理学に掠いては, 養育者や保育者 による子どもへの絵本の読み聞かせ場面における主要な要因と しては, 聴き手である子どもの特性に関するもの, 読み手であ る養育者・保育者の特性, 具体的には, 絵本の読み聞かせ方の 特性に関するもの, 読み聞かせに用いられる絵本の特徽に関す るものが指摘されている [3]. このうち, 特に本論文と関連が ある要因として, 読み聞かせに用いられる絵本の特徽を論じた 研究事例 $[16,19,32]$ も見られる. しかし, これらのいずれも, 実際に一定規模の種類の絵本を準備して子どもの反応事例を網 羅的に収集し記録したというものではない

また, 工学系の関連研究として, 文献 $[33,34]$ に拈いては, 発 声を伴う指さし, および, 指・手を用いたジェスチャーに焦点 を当て, 絵本レビューから網羅的に子どもの認知発達的事例を 収集した後，人手でそれらの類型化を行なっている，そして， それらの類型結果と, 発達心理学分野におけるこれまでの知見 との間で比較分析を行なった. これらの研究はいずれも, 子ど もの認知発達的反応のうちの特定の種類のものに着目して, 発 達心理学分野における報告事例との間で比較分析を行うもので ある, 一方, 本論文では, 特定の種類の反応ではなく, 絵本レ ビューより抽出される子どもの認知発達的反応およびその際に 用いられた絵本タイトルを網羅するとともに, 収集可能な事例 数の規模について調査を行い, 発達心理学分野における従来か 
らの知見と, 絵本レビューから収集可能な定量的情報との間の 比較分析を行うことを目的としている。

その他, 絵本レビューにおける子どもの反応は情報源とせ ず，絵本中のテキストそのものを情報源とする関連研究とし て, 絵本中の単語とその品詞情報を用いて対象年齢ごとの絵本 の特徵を分析する手法 [35], 絵本の文章の難易度から絵本の対 象年齢を推定する手法 [36], それらの難易度推定手法に基づき 絵本を推薦する手法 [37] 等が提案されている.

\section{5. おわりに}

本論文では, 従来の発達心理学研究における方式とは異な り，絵本のレビューが書き込まれるサイトを情報源として，絵 本に対する子どもの認知発達的反応が描写された絵本レビュー を収集してこれを分析対象とする方式を提案した。具体的に， 本論文では, 絵本レビューより抽出される子どもの認知発達的 反応およびその際に用いられた絵本タイトルを網羅するととも に, 収集可能な事例数の規模について調査を行い, 発達心理学 分野における従来からの知見と, 絵本レビューから収集可能な 定量的情報との間の比較分析を行った。その結果，本論文の提 案方式によって絵本レビューから収集した子どもの認知発達的 反応事例によって, 従来の発達心理学文献に打码知見を裏付 けることができた。ささらに，発達心理学文献での報告事例の規 模 ·種類とも上回る子どもの認知発達的事例を収集 ·類型化す ることができた，以上の結果によって，本論文の提案方式が有 効であることを示すことができた。

今後の課題として, 本論文に扔ける絵本の分類結果と, 発達 心理学分野における絵本の特徴の分類事例（例えば, 文献 [38]） 等との間の相関を分析することによって, 絵本レビューにおけ る子どもの認知発達的反応に基づく絵本の類型化が特異性を持 つのか否かについて分析を進める点が挙げられる，また，本論 文の著者の一人は, 発達心理学分野の研究活動の 1 つとして, 本論文で絵本レビューより収集した子どもの認知発達的反応事 例，および，その際に用いられた絵本の事例の全体を基礎デー タとして，1 節で言及した「子どもの認知発達の様々な局面に おいて効果があることが予測される多種類の絵本の事例を大規 模に収集しそれらを類型化すること, さらに, 各種類の絵本が, それぞれどのような種類の認知発達を子どもにもたらすのかに ついての知見を体系的に整理すること」に取り組んでいる。こ の取り組みは，本論文による工学系技術を拠り所とする研究の 成果を, 発達心理学分野の第一線の研究活動において取り込み 有効活用する極めて重要な取り組みであり，今後の研究の成果 が大いに期待される.

\section{参 考 文 献}

[1] 佐々木宏子: “絵本の心理学,”新曜社, 2000

[2] 秋田喜代美: “読書の発達心理学子どもの発達と読書環境,”国 土社, 1998 .

[3] K. L. Fletcher and E. Reese: "Picture book reading with young children: A conceptual framework," Developmental Review, Vol.25, No.1, pp. 64-103, 2005.

[4] 石川由美子, 前川久男: “絵本理解とその発達順序性: 発達援助と しての絵本利用の基礎研究,”心身障害学研究, Vol.20, pp. 83-91, 1996.
[5] 石川由美子, 前川久男: “絵本を媒介とした母親と子どもの読み 活動に関する研究の動向, ” 心身障害学研究, Vol.24, pp.227-240, 2000.

[6] A. Ninio and J. Bruner: "The achievement and antecedents of labelling," J. of Child Language, Vol.5, No.1, pp. 1-15, 1978.

[7] 佐藤鮎美, 内山伊知郎: “乳児期における絵本共有が子どもに 対する母親の働きかけに及ぼす効果: 絵本共有時間を増加させ る介入による縦断的研究から,”発達心理学研究, Vol.23, No.2, pp. 170-179, 2012.

[8] 齋藤有, 内田伸子: “母親の養育態度と絵本の読み聞かせ場面に おける母子相互作用の関係に関する長期縦断的検討, ”読書科学, Vol.55, No.1 · 2, pp. 56-67, 2013.

[9] 齋藤有, 内田伸子: “幼児期の絵本の読み聞かせに母親の養育態 度が与える影響:「共有型」と「強制型」の横断的比較, ”発達心 理学研究, Vol.24, No.2, pp. 150-159, 2013.

[10] 上原宏, 馬場瑞穂, 宇津呂武仁: “発達心理学の観点から見た絵本 レビュー中の子供の反応の分析, ”言語処理学会第 21 回年次大 会論文集,pp. 832-835, 2015.

[11] 齋藤有: “子どもの主体性を促す「共有型」養育態度の関わり： 安定した対話パタンへの着目, ”お茶の水女子大学グローバル $\mathrm{COE}$ プログラム「格差センシティブな人間発達科学の創成」, pp. 73-81, 2012.

[12] 今井和子: “なぜごっこ遊び? 幼児の自己世界のめばえとイメー ジの育ち,”フレーベル館, 1992.

[13] 井上洋平: “幼児期におけるふり行動の発達的研究,”立命館産業 社会論集, Vol.43, No.1, pp. 77-93, 2007.

[14] 加藤繁美: “心の育ちと対話する保育の本,” 学研教育出版, 2012.

[15] 明神もと子: “幼児のごっこ遊びの想像力について,” 北海道教育 大学釧路校研究紀要, No.37, pp. 143-150, 2005.

[16] 佐藤公代: “子どもの発達と絵本, ”愛媛大学教育学部紀要, Vol.51, No.1, pp. 29-34, 2004.

[17] 田口鉄久: “ごっこ遊びの研究-1・2 歳览のごっこ遊びと援助の あり方,”岐阜女子大学紀要, No.33, pp. 75-81, 2004.

[18] 山本直美: “子どものココロとアタマを育む毎日 7 分、絵本レッ スン,”日東書院, 2011.

[19] 吉田照子: “乳幼児の年齢別絵本リスト,”福岡女子短大紀要, No.71, pp.27-43, 2008.

[20] 佐々木宏子: “絵本は赤ちゃんから母子の読み合いがひらく世 界,”新曜社, 2006.

[21] 仲本美央: “現在の赤ちゃん絵本と周辺研究の動向,”育英短期大 学研究紀要, No.21, pp. 33-44, 2004.

[22] 関根佐也佳: “乳幼児期の絵本場面における母親の演出行動と質 問行動の役割: 情緒的な相互行為促進に影響を及ぼす行動様式 の検討,”お茶の水女子大学子ども学研究紀要, No.2, pp. 55-64, 2014.

[23] 外山紀子: “絵本場面における母親の発話,”教育心理学研究, Vol.37, No.2, pp. 151-157, 1989

[24] 菅井洋子: “乳児期の読書環境構成に関する発達研究-絵本場 面における実物への指さしを中心として,”発達研究, Vol.25, pp. 69-78, 2011.

[25] 秋田喜代美, 増田時枝: “絵本で子育て,”岩崎書店, 2009

[26] 関根佐也佳: “乳児期における絵本読み場面の母子相互行為の 変化: 縦断的観察による分析, ”人間文化創成科学論叢, Vol.15, pp. 221-229, 2012.

[27] 古市久子: “こどもの動きを引き出すオノマトぺ絵本,”東邦学誌, Vol.43, No.2, pp. 87-104, 2014.

[28] 近藤文里, 辻元千佳子: “絵本の選択が ADHD 児の読み聞かせに 及ぼす効果 (5) 一絵本におけるオノマトぺの作用-, ”滋賀大学教 育学部紀要 教育科学, No.62, pp. 15-29, 2012.

[29] 佐藤公治, 西山希: “絵本の集団読み聞かせにおける楽しさの共 有過程の微視発生的分析, ”北海道大学大学院教育学研究紀要, No.100, pp.29-49, 2007.

[30] 角田嚴: “子どもと絵本における相互主観性の成り立ち,”人間科 学研究, No.25, pp. 53-62, 2003.

[31] 佐々木宏子: “絵本と子どものこころ,” JULA 出版局, 1993.

[32] 石川由美子: “子どもの認知発達を促す最近接発達領域を生み 出す「場」としての絵本についての一考察, 聖学院大学論叢, 
Vol.22, No.1, pp. 165-179, 2009.

[33] H. Uehara, M. Baba, and T. Utsuro: "Utilizing texts of picture book reviews for extracting children's behavioral characteristics in language acquisition," Proc. 15th ICIS, pp.765-770, 2016.

[34] H. Uehara, M. Baba, and T. Utsuro: "Analyzing developmental characteristics of infants' finger/hand gestures- text analysis of picture book reviews-," 言語処理学会第 23 回年次大会論文集, pp. 430-433, 2017.

[35] 竹内孝, 石黒勝彦, 小林哲生, 藤田早苗, 平博順: “複合非負値行 列因子分解 (NM2F) による絵本データセットからの多角的パ 夕ーン抽出,”第 28 回人工知能学会全国大会論文集, 2014.

[36] 藤田早苗, 小林哲生, 南泰浩, 杉山弘晃: “幼児を対象としたテキ ストの対象年齢推定方法,”認知科学, Vol.22, No.4, pp. 604-620, 2015.

[37] 藤田早苗, 服部正嗣, 小林哲生, 奥村優子, 青山一生: “絵本検索シ ステム「ぴたりえ」-子どもにぴったりの絵本を見つけます-,” 自然言語処理, Vol.24, No.1, pp. 49-73, 2017.

[38] 無藤隆, 野口隆子, 木村美幸: “絵本とその魅力 - その編集・実 践・研究,”フレーベル館, 2017.

(2017 年 9 月 5 日 受付) (2018 年 3 月 5 日 採録)

[問い合わせ先］

テ305-8573 茨城県つくば市天王台 1-1-1

筑波大学システム情報系

宇津呂 武仁

TEL: 029-853-6537/5427

E-mail: utsuro@iit.tsukuba.ac.jp

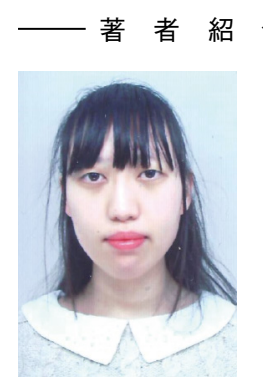

\section{架笠松 美歩 [非会員]}

2018 年筑波大学工学システム学類卒業. 現 在, 同大学大学院システム情報工学研究科 博士前期課程在学中. 自然言語処理の研究に 従事.

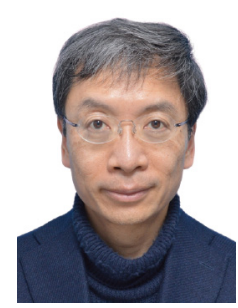

\section{上源宏 [非会員]}

2010 年筑波大学 ビジネス科学研究科修了. 博士 (経営学). 横浜銀行, 外資系 SIer, NTT ドコモを経て, 現在, 秋田県立大学システム 科学技術学部教授. テキストからのユーザー 行動分析, 農業データ分析等の研究に従事. 情報処理学会, 人工知能学会, 各会員.

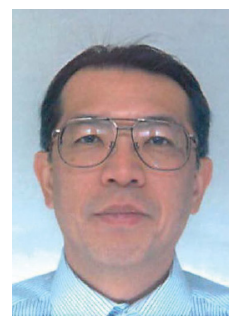

宇津呂武仁 [正会員]

1994 年京都大学大学院工学研究科博士課程修 了. 博士 (工学). 1994 年奈良先端科学技術 大学院大学情報科学研究科助手, 2000 年豊橋 技術科学大学情報工学系講師, 2003 年京都大 学情報学研究科講師. 2006 年筑波大学大学院 システム情報工学研究科助教授, 准教授を経 て 2012 年筑波大学システム情報系教授, 現在 に至る。自然言語処理, ウェブマイニングの 研究に従事.

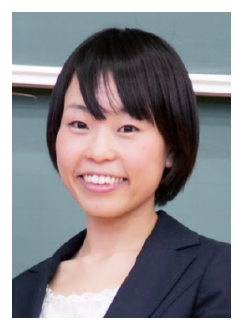

緕藤峟 [非会員]

2014 年扮茶の水女子大学人間文化創成科学 研究科博士後期課程卒業. 博士 (人文科学). ルーテル学院大学助教を経て, 現在, 聖徳大 学児童学部講師. 発達心理学の立場から絵本 の読み聞かせに関する研究に従事. 所属学会 は日本発達心理学会等.

\title{
Collecting and Categorizing Infants’ Developmental Reactions in Reviews on Picture Books and Classifying Picture Books
} by

\section{Miho KASAMATSU, Hiroshi UEHARA, Takehito UTSURO, and Yu SAITO}

\begin{abstract}
:
In order to examine how the stimuli of picture books induces a variety of reactions in infants, we take an approach of applying a text mining technique to a large amount of the reviews on picture books written by their parents or the childcare personnel. This paper especially studies the relation between the contents of picture books and an infant's developmental reactions. We further classify subcategories of an infant's developmental reactions as well as picture books according to the contents of picture books, and compare them with examples of infants' developmental reactions reported in the developmental psychology literature. We conclude that the proposed approach of applying a text mining technique to the reviews on picture books is quite effective.
\end{abstract}

Keywords: picture books, review analysis, developmental reactions

Contact Address: Takehito UTSURO

Faculty of Engineering, Information and Systems, University of Tsukuba

1-1-1 Tennnodai, Tsukuba 305-8573, Japan

TEL: +81-29-853-6537/5427

E-mail: utsuro@iit.tsukuba.ac.jp 